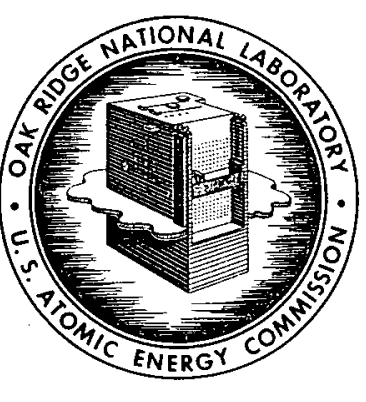

OAK RIDGE NATIONAL LABORATORY

operated by

UNION CARBIDE CORPORATION

NUCLEAR DIVISION

for the

U.S. ATOMIC ENERGY COMMISSION

ORNL - TM- 2532

DESIGN OF A LOOP FOR FISSION-PRODUCT

DEPOSITION TESTS UP TO $1500^{\circ} \mathrm{F}$

D. L. Gray

F. H. Neill

NOTICE This document contains information of a preliminary nature and was prepareo primarily for internal use of the Oak Ridge National Loboratory. It is subject to revision or correction and therefore does not represent o final report. 


\section{DISCLAIMER}

This report was prepared as an account of work sponsored by an agency of the United States Government. Neither the United States Government nor any agency Thereof, nor any of their employees, makes any warranty, express or implied, or assumes any legal liability or responsibility for the accuracy, completeness, or usefulness of any information, apparatus, product, or process disclosed, or represents that its use would not infringe privately owned rights. Reference herein to any specific commercial product, process, or service by trade name, trademark, manufacturer, or otherwise does not necessarily constitute or imply its endorsement, recommendation, or favoring by the United States Government or any agency thereof. The views and opinions of authors expressed herein do not necessarily state or reflect those of the United States Government or any agency thereof. 


\section{DISCLAIMER}

Portions of this document may be illegible in electronic image products. Images are produced from the best available original document. 
This report was prepared as an account of Government sponsored work. Neither the United States, nor the Commission, nor any person acting on behalf of the Commission:

A. Makes any wartanty or representation, expressed or implied, with respect to the accuracy, completeness, or usefulness of the information contained in this report, or that the use of any information, apparatus, method, or process disclosed in this seport may not infringe privately owned rights; or

B. Assumes any liabilities with respect to the use of, or for damages resulting from the use of any information, apparatus, method, or process disclosed in this report.

As used in the above, "person acting on behalf of the Commission" includes any employee or contractor of the Commission, or employee of such contractor, to the extent that such employee or contractor of the Commission, or employee of such contractor prepares, disseminates, or provides access to, any information pursuant to his employment or contract with the Commission, or his employment with such contractor. 
Contract No. W-7405-eng-26

Reactor Division

\title{
DESIGN OF A LOOP FOR FISSION-PRODUCT DEPOSITION TESTS UP TO $1500^{\circ} \mathrm{F}$
}

D. I. Gray

F. H. Neill

\begin{abstract}
$-\cdots$

\section{LEGAL NOTICE}

This report was prepared as an account of Government sponsored work. Neither the United States, nor the Commission, nor any person acting on behalf of the Commission:

A. Makes any warranty or representation, expressed or implied, with respect to the accuracy, completeness, or usefulness of the information contained in this report, or that the use of any information, apparatus, method, or process disclosed in this report may not infringe privately owned rights; or

B. Assumes any liablitites with respect to the use of, or for damages resulting from the use of any information, apparatus, method, or process disclosed in this report.

As used in the above, "person acting on behals of the Commission" includes any employee or contractor of the Commission, or employee of such contractor, to the extent that such employee or contractor of the Commission, or employee of such contractor prepares, disseminates, or provides access to, any information pursuant to his employment or contract with the Commission, or his employment with such contractor.
\end{abstract}

\section{JUNE 1969}

\author{
OAK RLDGE NATIONAL LABORATORY \\ Oak Ridge, Tennessee \\ operated by \\ UNION CARBIDE CORPORATION \\ for the \\ U.S. ATOMIC ENERGY COMMISSION
}




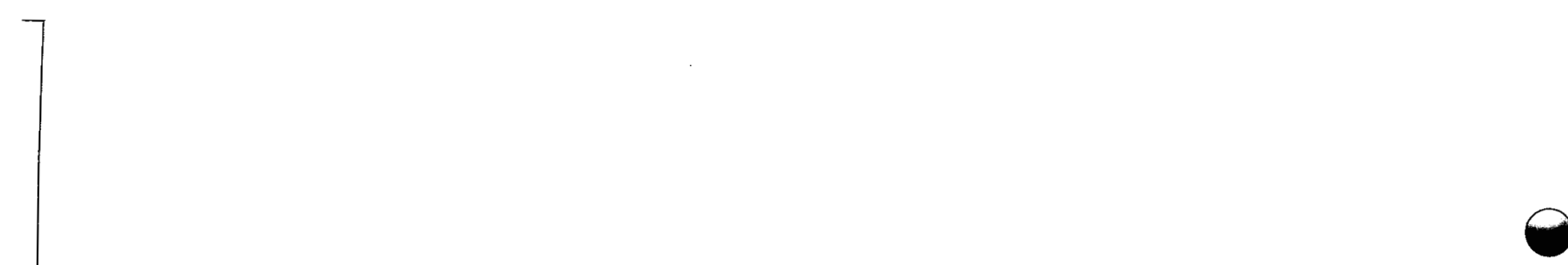

0
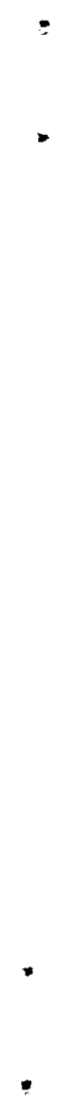

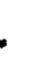

.

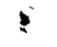

$\bullet$ 


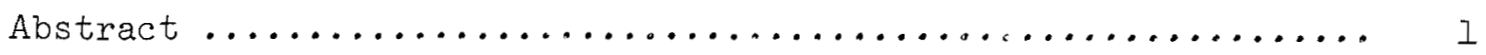

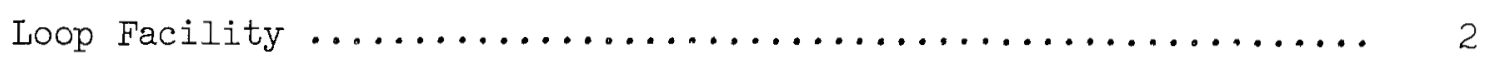

Loop Components .............................. 2

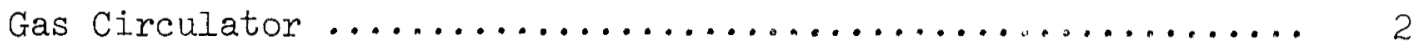

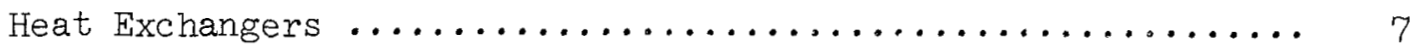

Fission-Product Injection System $\ldots \ldots \ldots \ldots \ldots \ldots \ldots \ldots \ldots$

Deposition Section $\ldots \ldots \ldots \ldots \ldots \ldots \ldots \ldots \ldots \ldots \ldots \ldots \ldots \ldots \ldots$

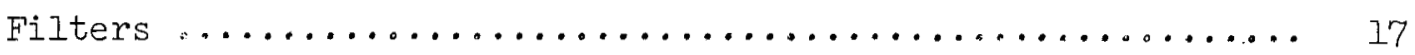

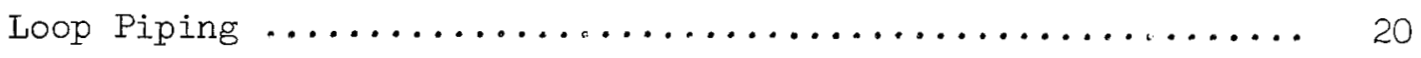

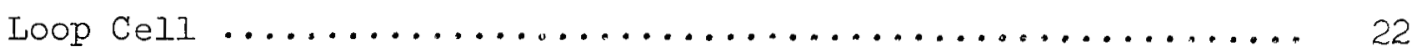

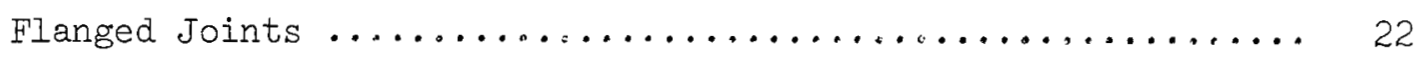

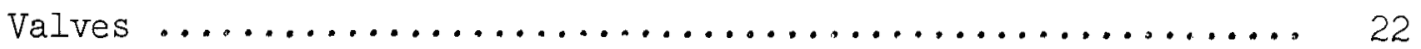

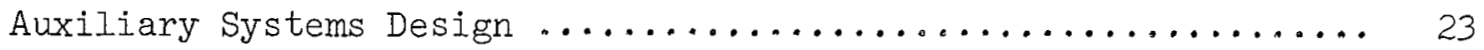

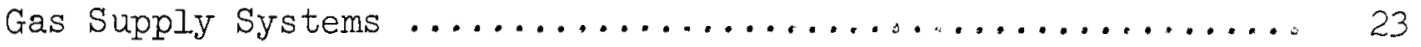

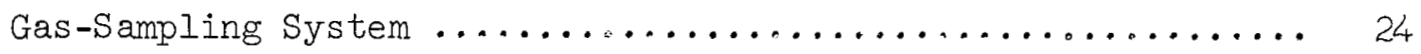

Loop-Evacuation, Purge, and Pressure-Relief System ....... 24

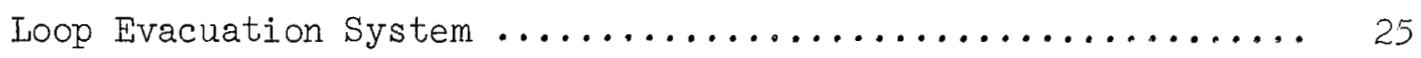

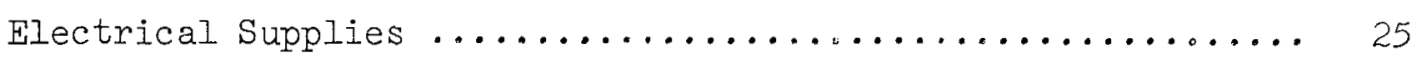

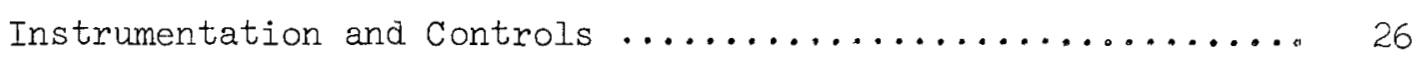

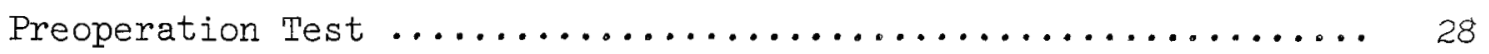

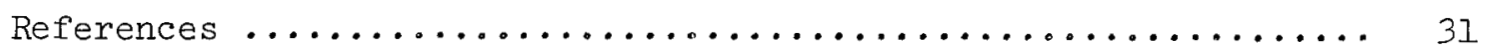

Appendix A. Modification of a Greenbrier Gas Chromatograph for Increased Sensitivity ................. 33 


\title{
DESIGN OF A IOOP FOR FISSION-PRODUCT DEPOSITION
}

TESTS UP TO $1500^{\circ} \mathrm{F}$

D. I. Gray F. H. Neill

\begin{abstract}
The original fission-product deposition loop was modified to provide capability for simulating more realistically the temperature gradients in an advanced gas-cooled reactor circuit. A heater and cooler were added to permit operation of the test section to $1500^{\circ} \mathrm{F}$. Both the isothermal and thermal gradient test sections were lengthened.

This report describes the operating conditions and design capabilities of the modified system and presents a comprehensive description of the loop components and auxiliary systems.

Keywords: fission products, deposits, AGR, simulation, coolant loop, high temperature.
\end{abstract}

A program was undertaken to investigate, both analytically and experimentally, the transport and deposition of fission products from a flowing helium stream. In the initial phase of the experimental program at the Oak Ridge National Laboratory, a loop was used that was capable of operating with a coolant temperature up to $600^{\circ} \mathrm{F}$. The results obtained from this phase of the experimental program were reported previously. ${ }^{1,2}$

A temperature restriction was imposed on the loop because of the loop compressor. Therefore, to obtain a temperature range in the deposition section of the loop that would more nearly simulate the temperatures expected in an advanced gas-cooled reactor circuit, a cooler and heater were added to the loop circuit. During rebuilding of the loop several other improvements were made to the facillity, such as rearrangement of the deposition section, installation of a new fission-product injector, and the addition of two full-flow traps.

This report describes the rebuilt loop as it will be used in future fission-product deposition experiments. 


\section{Loop Facility}

The fission-product deposition (FPD) loop facility consists of a metal-lined cell 25 by 39 ft with a ventilation system; a high-pressure high-temperature experimental loop; handling equipment for the loop fission-product injector; an auxiliary cooling water circuit; and instrument panels, electrical heat supplies, and control circuits. The test loop consists of a heater, cooler, gas circulator, fission-product injection section, gas-cleanup section, fission-product filter, and a fission-product deposition section. The locations of the various components in the loop are shown schematically in Fig. 1, and the deposition section is shown in Fig. 2. Criteria for the loop included a design pressure of 226 psig and an ultimate inlet temperature to the deposition section of $1500^{\circ} \mathrm{F}$.

\section{Loop Components}

\section{Gas Circulator}

The FPD loop compressor (ORNL model HECT-2) ${ }^{3}$ is electrically powered and hermetically sealed. Its impeller is the regenerative type designed for low flows and high discharge heads. The rotary assembly is mounted on grease-lubricated precision ball bearings that have an operating life of approximately $6000 \mathrm{hr}$, at which time they are routinely replaced.

The impeller for the HECT-2 compressor is disk shaped, with radial vanes machined into each side around its periphery (Fig. 3). The housing surrounding the bearings and the motor contains water-cooled passages and is bolted to the compressor volute. The entire assembly is mounted in a cylindrical pressure vessel $20 \mathrm{in.}$ in diameter and 19 in. long. Cooling water is supplied to the motor casing through pipe studs welded to the pressure vessel. Conax connectors and insulated cables with hermetic connectors seal the electrical and thermocouple wires penetrating the pressure vessel. Typical measured performance data for the HECT-2 compressor are shown in Fig. 4, and design performance values are listed in Table 1 .

The design, manufacture, and testing of all pressure-containing parts of the FPD loop compressor assembly conformed to the practices outlined 


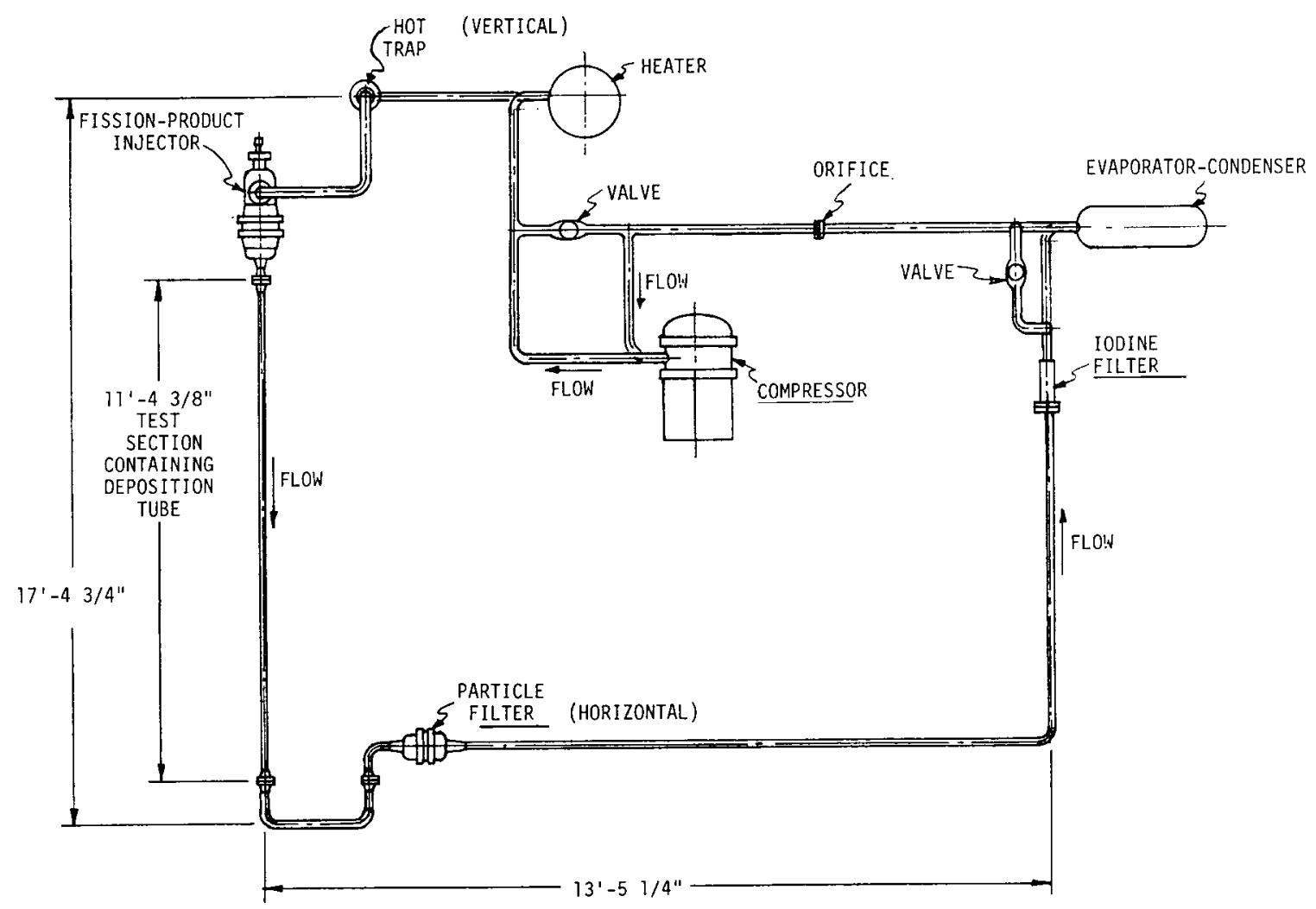

Fig. 1. Schematic Diagram of FPD Loop Piping and Components. 


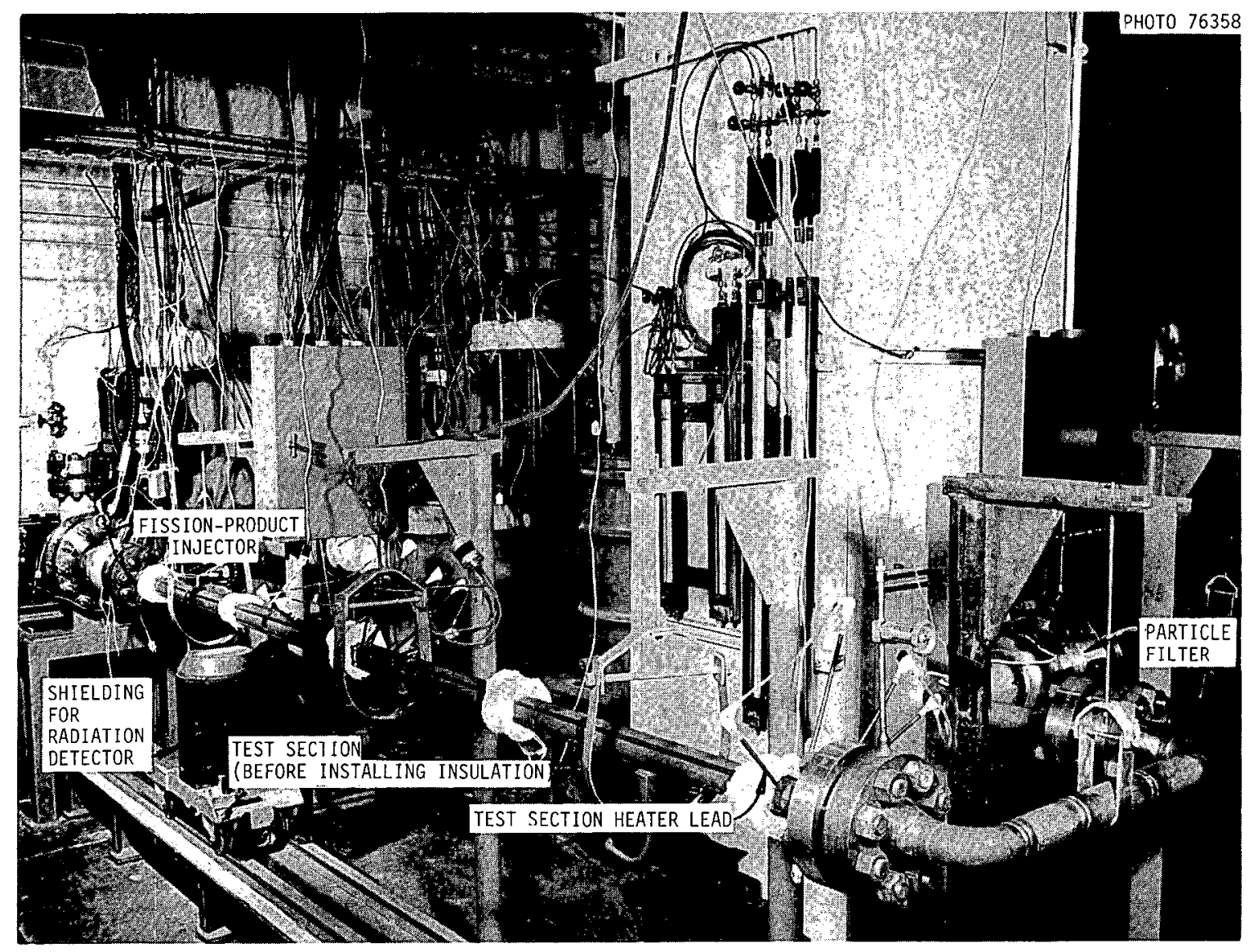

Fig. 2. Rebuilt Loop for Fission-Product Transport and Deposition Experiments. 


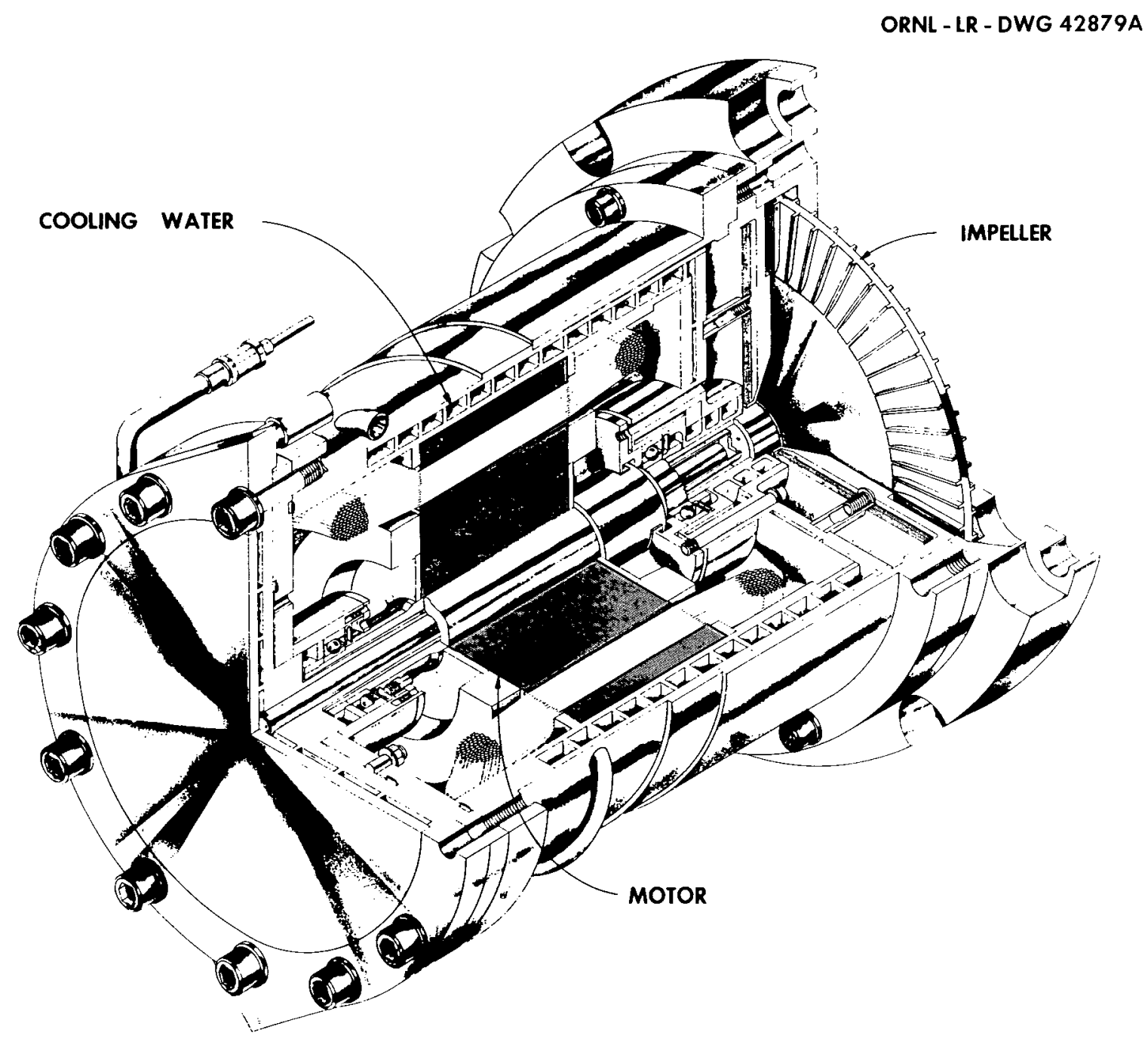

Fig. 3. ORNL Model HECT-2 Grease-Bearing Helium Compressor. 


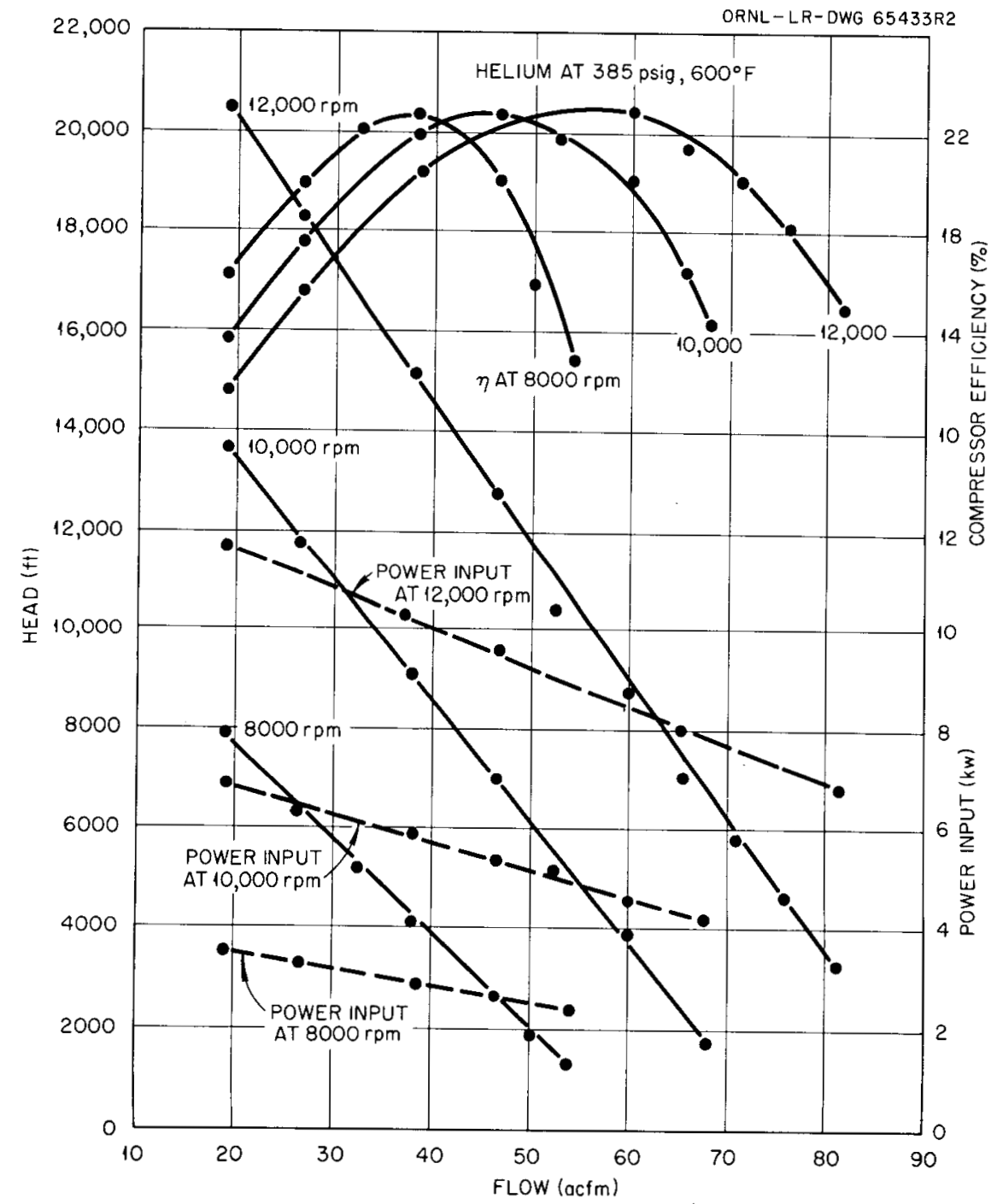

Fig. 4. Measured Head Versus Flow Data for HECT-2 Compressor. 
Table 1. Compressor Design Parameters

\begin{tabular}{lll}
\hline & Normal & Limiting \\
\hline Inlet pressure, psia & 240 & 400 \\
Inlet temperature, ${ }^{\circ} \mathrm{F}$ & 600 & 650 \\
Outlet temperature, ${ }^{\circ} \mathrm{F}$ & 620 & 650 \\
Flow rate, cfm (actual) & 47 & 50 \\
Impeller speed, rpm & 11,800 & 12,500 \\
Motor power at design conditions, hp & 12 & \\
Motor voltage & 208 & \\
Electrical frequency, Hz & 400 & 416 \\
Continuous operation without maintenance, hr & 6,000 & 7,500 \\
Cooling water & & \\
Flow, gpm & 2.25 & 1.5 \\
Inlet temperature, ${ }^{\circ} \mathrm{F}$ & 70 & 120 \\
Temperature rise, ${ }^{\circ} \mathrm{F}$ & 10 & 30 \\
Inlet pressure, psig & 35 & 100 \\
Pressure drop, psi & 35 & 30 \\
Discharge temperature, ${ }^{\circ} \mathrm{F}$ & 80 & 150 \\
Discharge pressure, psig & 0 & 90 \\
\hline
\end{tabular}

in the ASME Boiler and Pressure Vessel Code. The pressure vessel for the HECT-2 compressor is fabricated from type $304 \mathrm{H}$ stainless steel.

An isolated circulator cooling-water system is required to provide double containment of fission products. If a leak developed in the circulator cooling water passages, any contamination that had entered the circulator pressure vessel from the helium system could enter the cooling water and contaminate that system. Therefore, a closed system composed of a 55-gal stainless steel water reservoix (drum), a circulating pump, flow indicator with low-flow alarm, and heat exchanger was assembled to supply the cooling water to the helium circulator.

Heat Exchangers

The heater, evaporator, and condenser were originally designed and fabricated for GCR-ORR-Loop II, which is a gas-cooled in-pile loop ${ }^{4}$ 
installed in the Oak Ridge Research Reactor. Loop II is now in standby, so the spare components were made available.

Without modifications the components were able to provide the following coolant conditions for the FPD loop:

1. an upper normal operating temperature limit of $600^{\circ} \mathrm{F}$ for the compressor inlet gas temperature,

2. a helium flow range from 0 to a maximum of approximately $278 \mathrm{lb} / \mathrm{hr}$ at a 226-psig loop pressure,

3. a maximum gas temperature of $1500^{\circ} \mathrm{F}$ entering and leaving the injector and isothermal test section.

Heater. The heater ${ }^{5}$ is a four-pass cross-flow unit containing 60 electric heating elements in eight staggered rows (Fig. 5). The elements are 5/8-in.-diam (nominal) Inconel-sheathed cartridge heaters manufactured under the trade name "Firerods" by the Watlow Electric Manufacturing Company. Each cartridge is rated at $4.7 \mathrm{kw}$, so the maximum installed capacity is $282 \mathrm{kw}$. To increase heater life, the electrical circuits were designed to limit the power to about $90 \mathrm{kw}$. Fourteen I/I6-in.-OD Chromel-Alumel thermocouples sheathed in type 347 stainless steel were installed at various locations in the heater bundle to monitor sheath temperatures. Normally the heater sheath temperature is held below $1500^{\circ} \mathrm{F}$.

The individual heater elements are connected in three separately controlled parallel circuits, and the power is adjustable by three variabletransformer banks. The element terminals and leads are located in a nitrogen-buffered region (see Fig. 5) $10 \mathrm{l} / 2 \mathrm{in}$. in diameter and $10 \mathrm{l} / 2$ in. long that is approximately $1 \mathrm{l} / 2 \mathrm{ft}$ from the heater section. This terminal region is separated from the heated region by the header sheet to which the heater sheaths are welded.

The 13 1/8-in.-diam 7/15-in.-thick heater pressure shell is fabricated from type $347 \mathrm{H}$ stainless steel. The shell is protected from high temperature by internal reflective insulation composed of "high-luster" stainless steel sheets spaced about $1 / 8$ in. apart to a total thickness of $11 / 2$ in.

Performance data obtained from tests of GCR-ORR loop II main heat exchangers ${ }^{4}$ are plotted in Fig. 6. Performance tests made after the heater was installed in the FPD loop revealed that at the lower flow rate of the 


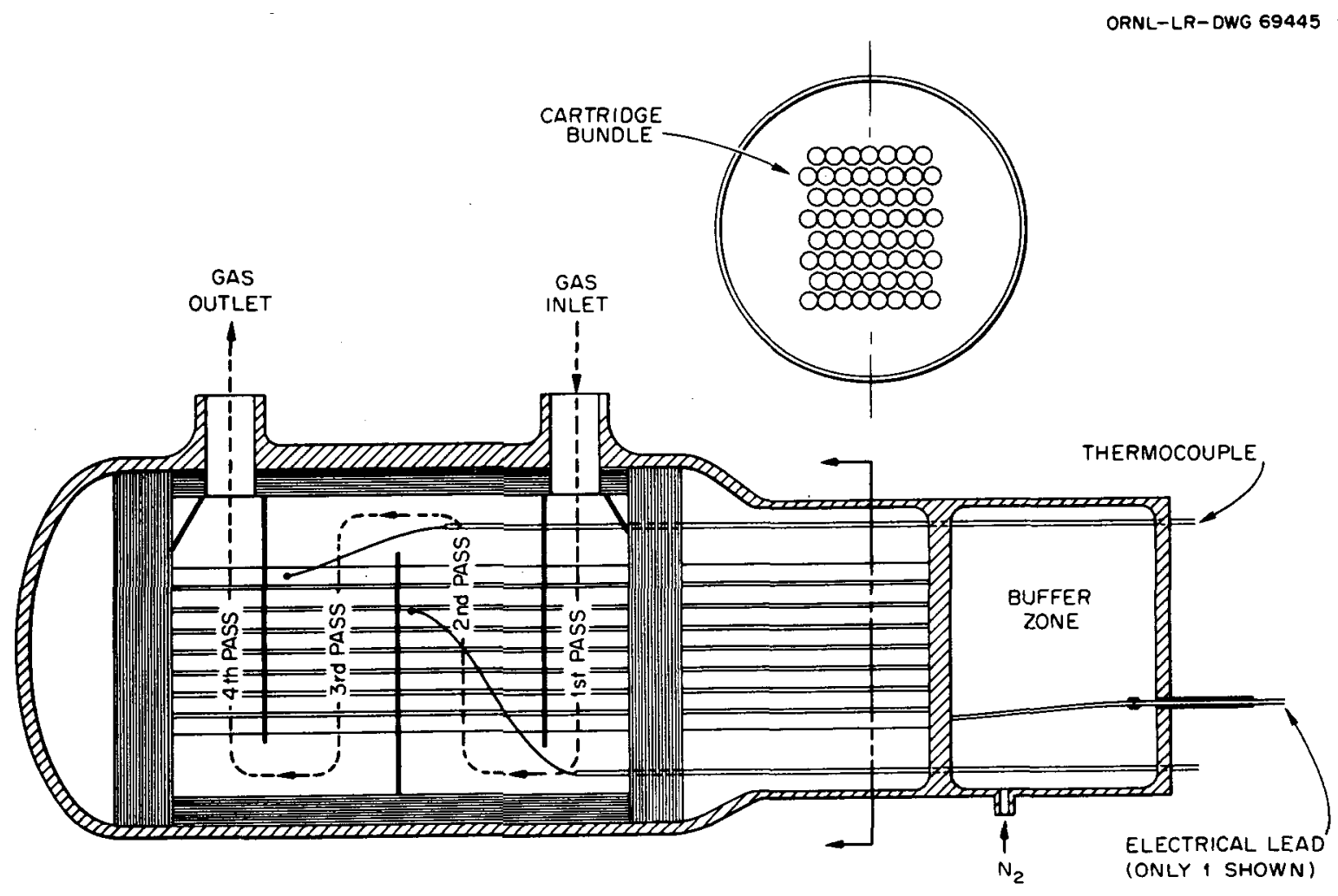

Fig. 5. Cross-Sectional Diagram of Gas Heater. 


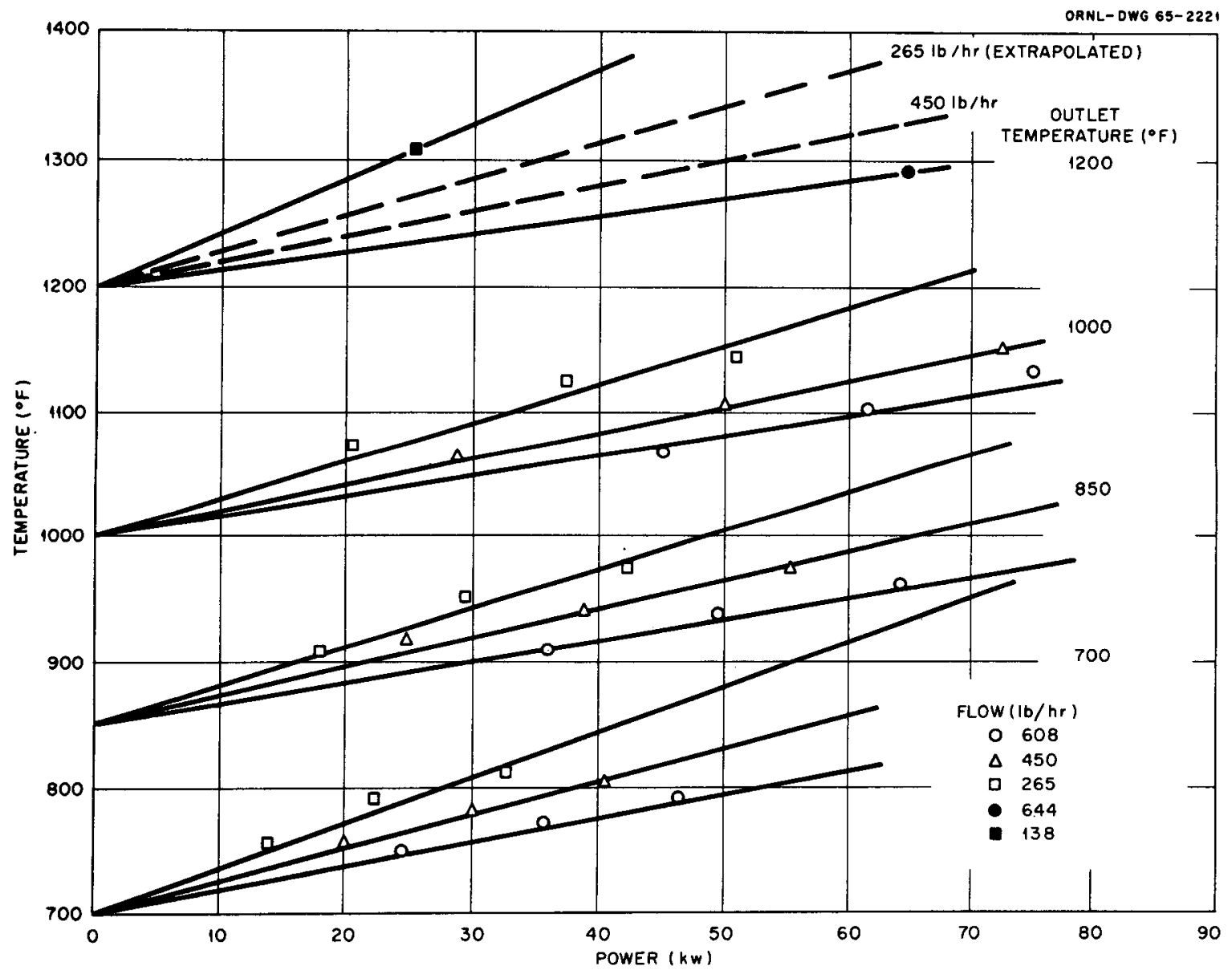

Fig. 6. Maximum Heater Cartridge Temperature Versus Heater Power as a Function of Flow and Outlet Temperature. 
FPD loop $\left(237 \mathrm{Ib} / \mathrm{hr}\right.$ ), a heater sheath temperature of $1475^{\circ} \mathrm{F}$ was reached when the bulk helium temperature leaving the heater was $1200^{\circ} \mathrm{F}$. The desired exit temperature of $1500^{\circ} \mathrm{F}$ can probably be reached by installing clam-shell heaters on the outlet piping of the heater.

Cooler. A gas cooler is required in the system to lower the temperature of the loop coolant to at least $600^{\circ} \mathrm{F}$, the normal allowable inlet temperature at the compressor section. An evaporative cooler is used on the FPD loop that is composed of two units, a water evaporator and a condenser. The condenser is located directly above the evaporator unit and is cooled by a process water circuit. The evaporator and condenser system is initially filled under vacuum with distilled water to a level approximately 2 in. above the top tubes in the evaporator. Figures 7, 8, and 9 show, respectively, cross-sectional views of the evaporator cooler and the condenser and a view of the units installed in the FPD loop.

In the evaporator the helium stream passes through U-tubes immersed in demineralized water. Heat is transferred to boil the water, and the generated steam rises to the condenser, where it is condensed on the outside of the process water-cooled tubes. The condensate returns to the evaporator by gravity flow to complete the water-steam cycle. The closed steam-water circuit is part of a double-containment scheme for the loop to avoid contamination of a cooling water circuit.

The evaporator pressure vessel is fabricated of Inconel and is cylindrical ( $8 \mathrm{I} / 2 \mathrm{in.}$ in diameter and about $26 \mathrm{in.} \mathrm{long).} \mathrm{It} \mathrm{is} \mathrm{partitioned}$ into a gas region and a demineralized water region by a tube sheet to which the seven Inconel U-tubes ( $3 \mathrm{ft}$ long and 3/4 in. in diameter) are welded. The gas region is further divided into inlet and exit chambers by a thin horizontal baffle. A bypass line around the evaporator and a throttle valve are provided to permit modulation of the helium temperature leaving the unit.

The condenser is of a standard shell-and-tube design. The building cold process water supply provides the heat sink in a single pass through the condenser tubes. Flow is regulated by a hand-operated control valve to a rate indicated by a variable orifice meter. The shell, which is 8-in. sched. -40 pipe (type $347 \mathrm{H}$ stainless steel) contains 37 tubes (type 


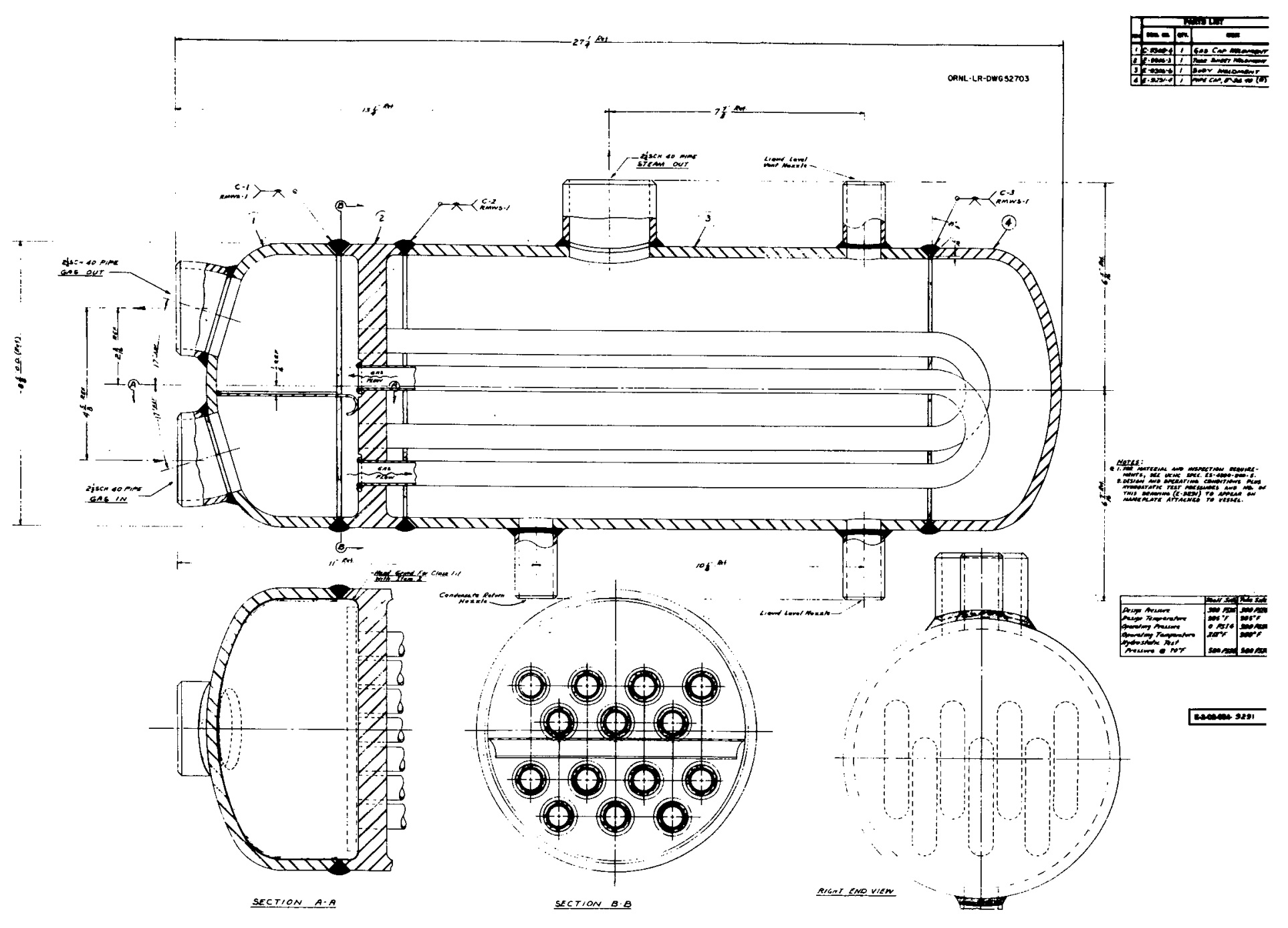

Fig. 7. Evaporator Unit for FPD Loop Cooler. 


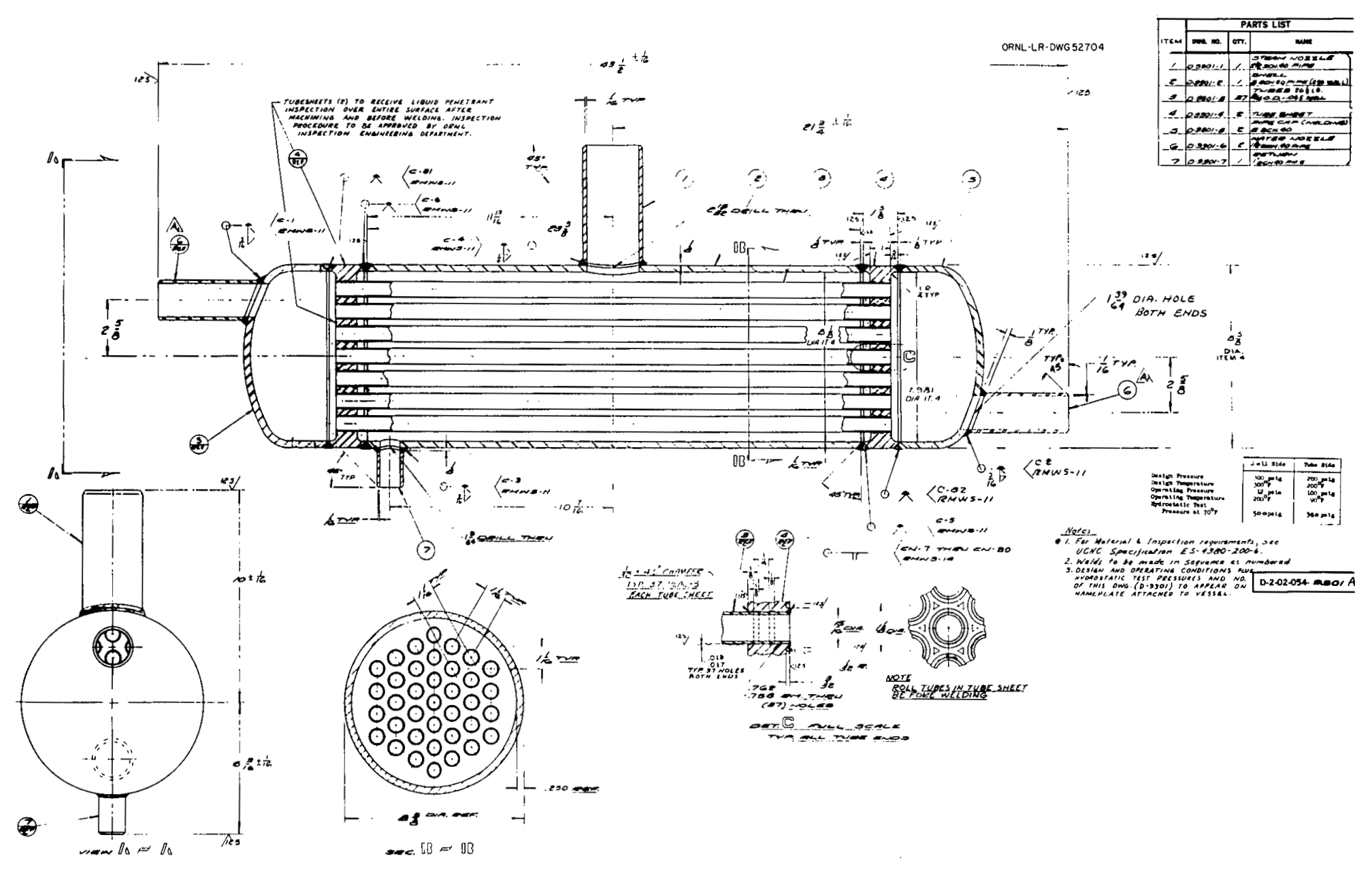

Fig. 8. Condenser Unit for FPD Loop Cooler. 


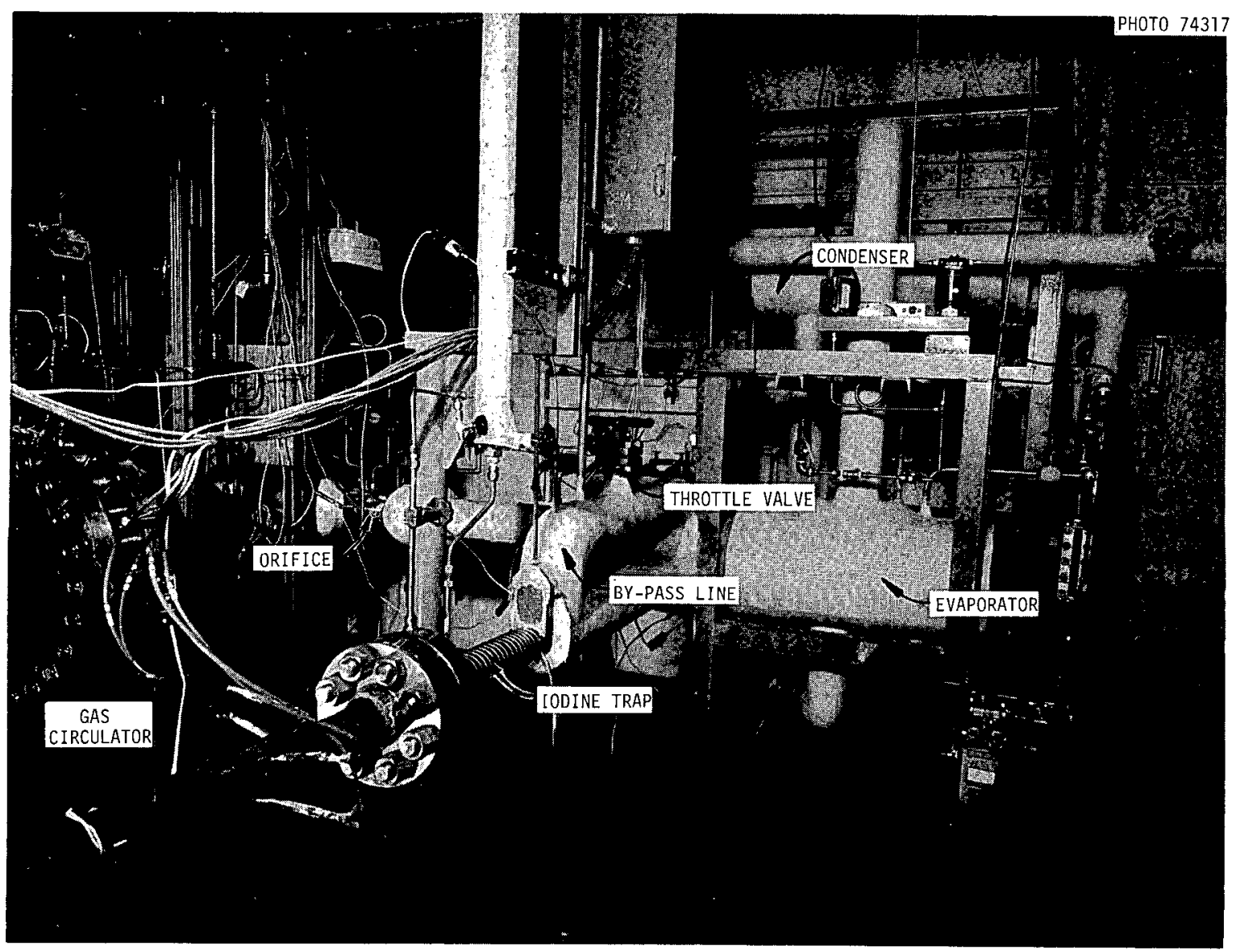

Fig. 9. Evaporator and Condenser Installed in Loop. 
304 stainless steel) that are $3 / 4 \mathrm{in.} \mathrm{OD} \mathrm{and} 26 \mathrm{in.} \mathrm{long} \mathrm{and} \mathrm{are} \mathrm{welded}$ into headers at each end. The steam line connecting the evaporator and the condenser contains a pressure-relief valve set to relieve at 225 psi and has a relieving capacity of 533 lb of steam per hour.

Fission-Product Injection System

Space is provided in the loop circuit for insertion of a fissionproduct injector assembly. The particular type of injector used will depend on the requirements of the specific experiment. In earlier lcop experiments, iodine in a liquid solvent was injected into the flowing helium by a small positive-displacement pump. Following this, iodine in the form of palladium iodide was inserted into the injector in sealed capsules. By remotely breaking the seal and then heating the capsule to above the dissociation temperature of palladium iodide the iodine was allowed to diffuse into the system.

The initial experiments scheduled for the rebuilt loop are designed for studying the evaporation, diffusion, and deposition of cesium and strontium in a turbulently flowing helium stream. The injector for this series of tests is shown in Fig. 10. Sealed capsules of cesium or strontium will be inserted into the capsule breaker assembly, which will then be installed in the injector pressure vessel and sealed into place by means of the small mechanical joint at one end of the unit. Following evacuation and pressurization of the loop with helium the sealed capsiles will be broken remotely. By heating the source with the source heater, the metal vapor will diffuse down the length of the molybdenum tube into the graphite evaporator tube. By proper control of the graphite evaporator temperature with an induction heater, the vapor will be made to diffuse through the graphite tube into the main loop coolant stream. The rate of vapor generation will be determined by the source vapor pressure, which will be controlled by the source heaters. Diffusion coefficients of the isotope in graphite can be determined by subsequent sectioning of the graphite evaporator tube. 


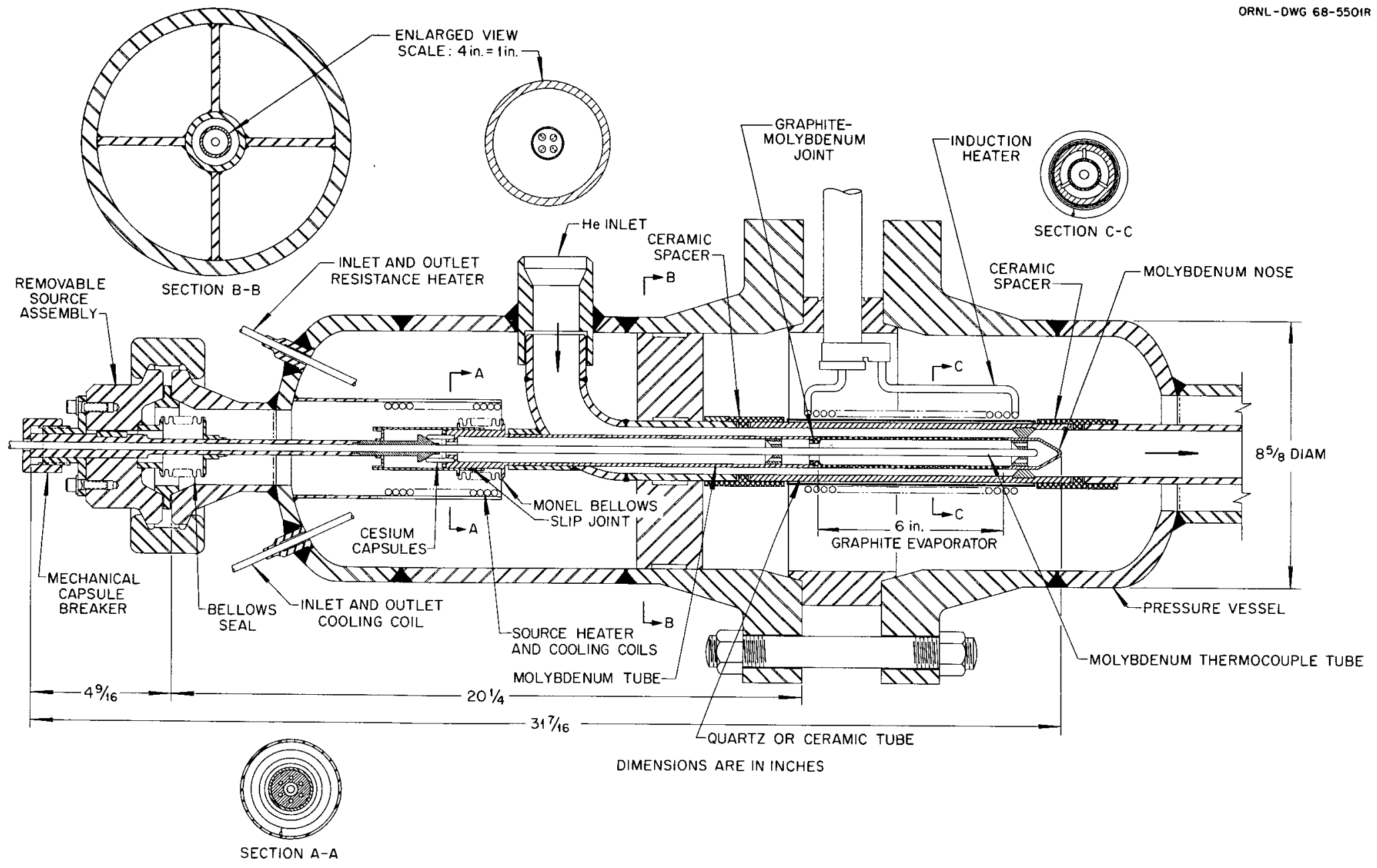

Fig. 10. Isotope Injector for FPD Loop. 
Deposition Section

Downstream of the fission-product injector assembly, space is provided for a fission-product deposition and monitoring section. The deposition section consists of an ll-ft 4-in. length of 2-in. sched.-80 pipe with joints at each end for attachment to the loop circuit and for insertion of a l-in.-diam liner. Sheathed heaters are equally spaced about the periphery of the 2-in, outer pipe on the two $45^{\circ}$ planes with the horizontal. This arrangement removes the heaters from the direct line of sight of a collimated gamma detector, which is mounted on tracks directiy below the deposition tube.

An additional $19 \mathrm{ft}$ of deposition surface can be provided downstream of the first section, described above, by the removal of the horizontal fission-product trap (see Fig. I). This second section is fabricated from 2-in. sched. -80 type 304 stainless steel pipe. It is heated by tubular heaters attached to the outer surface of the pipe in the same manner as the heaters for the first deposition section. Each group of heaters is controlled by a separate variable transformer. Individual controls on the heaters, in addition to variable thicknesses of piping insulation, enable the operator to impose controlled thermal gradients along the deposition tube.

\section{Filters}

Three different types of filters are available for use on the loop, The iodine filter, which was used in the original system, is shown in cross section in Fig. 11. This filter is a water-cooled assembly packed with silver-plated bronze wool. It is most useful for removing iodine from the coolant stream to prevent its recirculation into the test section.

The second type of filter is a full-flow hot trap, shown in Fig. 12, which is located upstream of the injector assembly and contains a getter material (uranium turnings) to remove oxidizing impurities in the helium. The hot trap is designed to operate at the outlet gas temperature of the heater, approximately $1200^{\circ} \mathrm{F}$. The filter vessel is lined with a fibrous insulation which is contained by an irner stainless steel liner. 


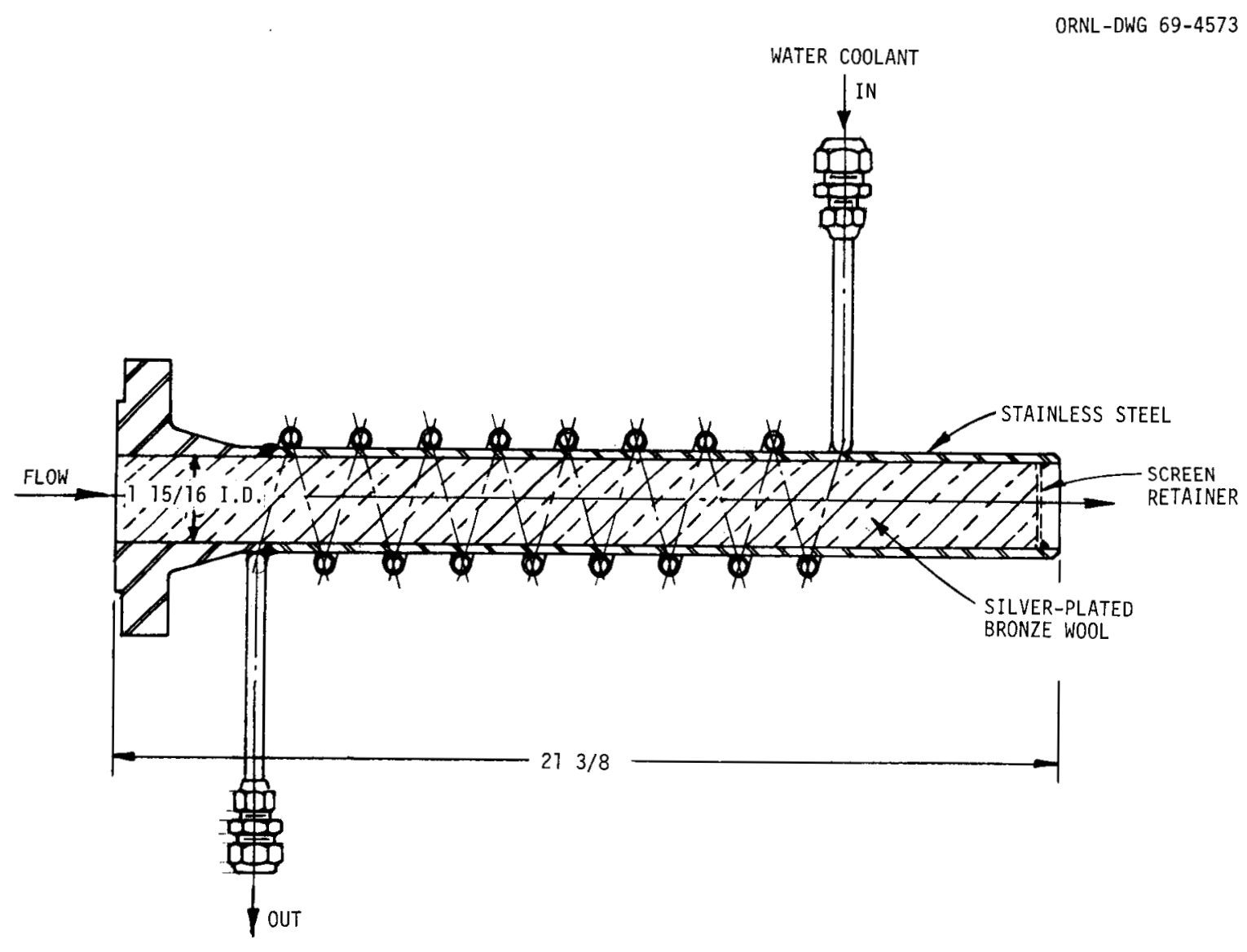

Fig. 11. Iodine Filter. 
ORNL-DWG $69-4574$

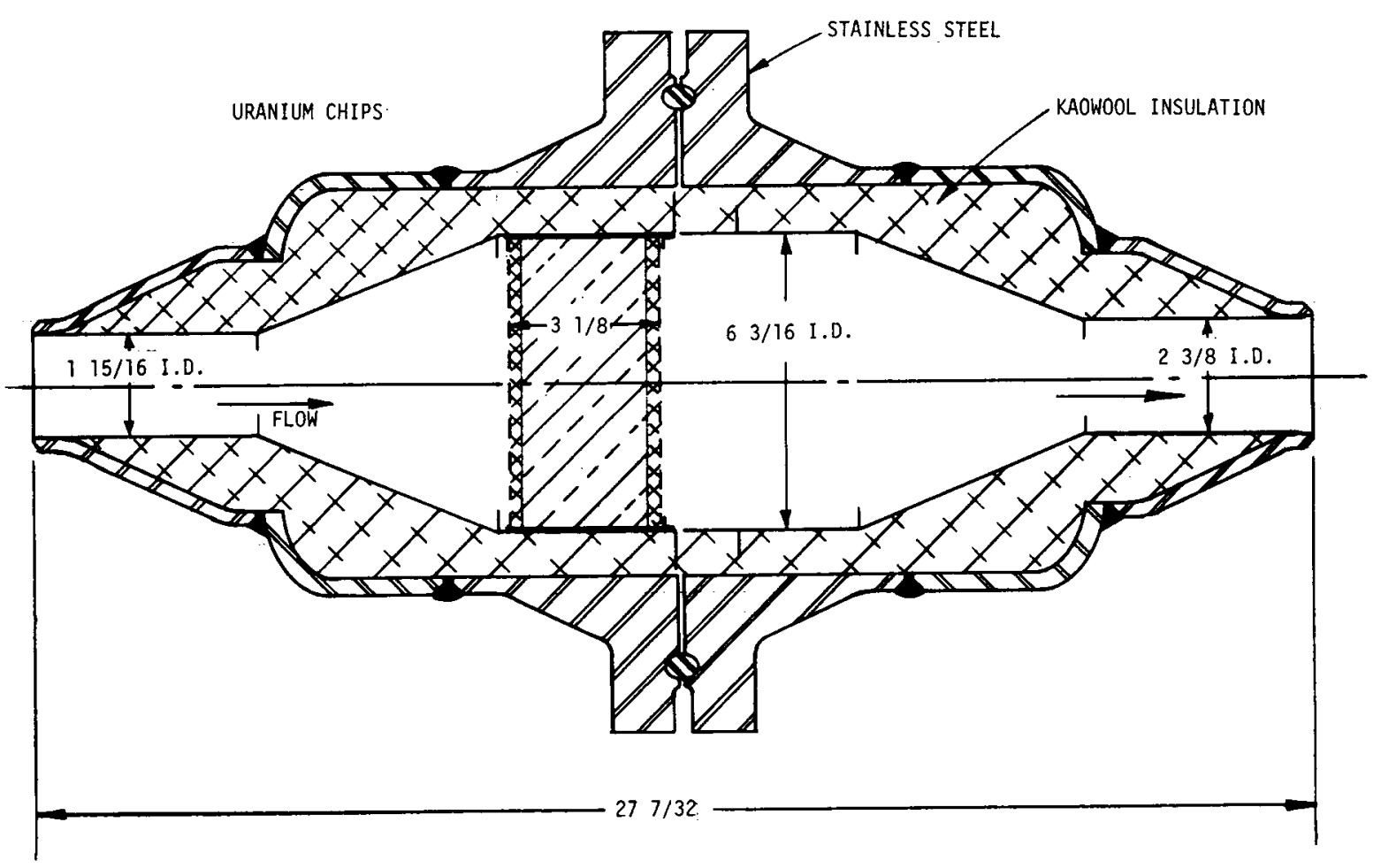

Fig. 12. Full-Flow Hot Trap. 
The third type of filter, shown in Fig. 13, can be used in place of the iodine filter, and it is located directly downstream of the deposition section of the loop. It is designed to remove particulate matter from the coolant stream and thereby prevent contamination of the entire loop system when long-lived isotopes are used as the tracer element. The filter vessel is lined with fibrous insulation, which is retained by an inner stainless steel liner.

\section{Loop Piping}

The piping for the FPD loop was chosen from readily available pipe in a size and wall thickness to permit high coolant pressure, and thus high Reynolds numbers, in the deposition section. The choice was 2-in-IPS sched.-80 pipe, which will permit a maximum loop pressure of 226 psig at the desired temperature of $1500^{\circ} \mathrm{F}$.

The loop contains three temperature zones because of temperature restrictions on components. A high-temperature zone, from the exit of the heater to the iodine filter downstream of the test section, is limited to operation at $1500^{\circ} \mathrm{F}$ and $226 \mathrm{psig}$. The intermediate-temperature zone, from the downstream end of the iodine filter to the inlet of the evaporator, is designed for operation at maximums of $993^{\circ} \mathrm{F}$ and 226 psig established by a stress analysis of the evaporator. The low-temperature zone constructed of sched.-40 pipe, from the outlet of the evaporator to the inlet of the heater, is limited to a maximum of $600^{\circ} \mathrm{F}$ by the compressor design. Heat losses from the piping are sufficiently high that the circulating helium does not overheat the downstream temperature-restricted zones.

The loop is protected from overpressurization (as required by section VIII of the ASME Pressure Vessel Code) by a relief valve, set at 248 psig, which was placed as near the ventilation exhaust system as possible. Since the Code does not permit an obstruction downstream of a relief valve, the valve is vented directly to the cell. The exhaust fan circulates 14,000 cfm of air through the cell to carry any released iodine out the stack or, at least, prevent back diffusion of the iodine to the front part of the cell.

The FPD loop was analyzed for stresses by using the MEC-21 PipingFlexibility Computer Program, ${ }^{6}$ and the stresses due to thermal expansion 
ORNL-DWG $69-4575$

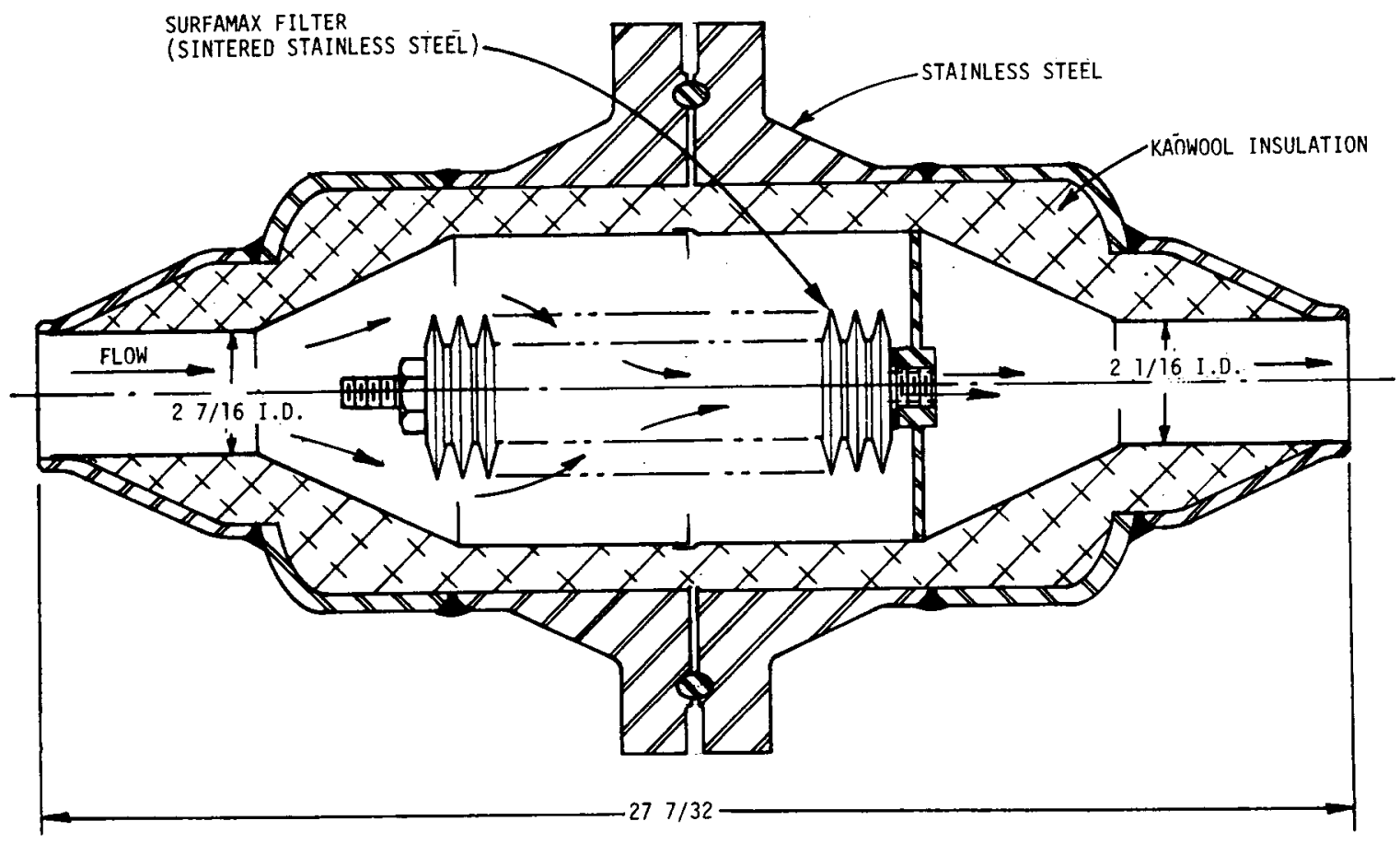

Fig. 13. Particle Filter. 
and weight loading of the system were shown to be within the allowable stresses permitted in the Code for Pressure Piping, ASA-B31-1-1955.

\section{Loop Cel1}

The loop is situated in a metal-lined room $40 \times 25 \times 20 \mathrm{ft}$ high on the first floor of Building 9201-3 in the Y-12 Area in space previously used for the Hydrogen Autoclave Experiment. Air from the interior of the building enters the cell through double doors at the front and is exhausted at the rear through a 70-ft-high stack to an exhaust fan located on the roof of the building. The ventilation system circulates $14,000 \mathrm{cmf}$ through the cell, which is theoretically equivalent to a change of air in the cell every $1.4 \mathrm{~min}$. If a loop containing a 5 -mc source ruptured and all the activity remained airborne, the cell atmosphere would be reduced to $9 \times 10^{-9}$ $\mu \mathrm{c} / \mathrm{cc}$ within $10 \mathrm{~min}$ with this ventilation rate $\left(9 \times 10^{-9} \mu \mathrm{c} / \mathrm{cc}\right.$ is the continuous 40-hr week occupational exposure limit in air). ${ }^{7}$ Smoke-injection techniques were used to investigate the ventilation within the cell, and the minimum air velocity ${ }^{8}$ measured was about 1 fps.

\section{Flanged Joints}

The pipe connections between the removable sections and the fixed parts of the loop are 2500-Ib-rated ring-joint flanges. In each set of flanges, one flange is drilled, so that a buffer gas (nitrogen) can be introduced into the ring groove. The ring is drilled with two holes on the pitch diameter so that the gas can pass into the ring groove of the other flange. The nitrogen is supplied at a pressure approximately 2 psi below the helium system pressure and thus acts as a buffer gas to minimize helium leakage past the sealing rings into the cell. The differential pressure between the helium and nitrogen systems is automatically con-m trolled.

\section{Valves}

Four main loop valves are available for use in the FPD loop. Two of the valves are for bypass service (Fig. 1), and the other two valves can be installed for use as blocking valves when it is desired to evacuate the derosition sections separately from the remainder of the loop. 
One bypass valve is located in a recirculation loop around the compressor. This is a bellows-sealed globe valve fabricated by the MasonNeilan Company from type 316 stainless steel. This valve was certified for service at $600^{\circ} \mathrm{F}$ and $400 \mathrm{psig}$ by the ORNL Inspection Engineering Department.

A second bypass valve allows the helium to short-circuit the evaporative cooler. It is a 2-in. No. 3221-B6 Robertshaw bellows-sealed plug valve with a type 347 stainless steel body and bonnet and a type 321 stainless steel bellows. This valve is rated for a 500-psi differential across the bellows at a temperature of $1250^{\circ} \mathrm{F}$.

The two block valves are Mason-Neilan $21 / 2-i n$. "Y" style bellowssealed plug valves. The valve body is type 316 stainless steel and Hastelloy $C$ is used for the bellows. These valves are rated at 50 psi applied internally with the valve in the open position at $1600^{\circ} \mathrm{F}$ and have been certified for operation at $226 \mathrm{psig}$ and $990^{\circ} \mathrm{F}$. Because of the lowtemperature rating they will not be used in the next series of experiments.

All other valves used for primary containment are also bellows-sealed valves.

\section{Auxiliary Systems Design}

The auxiliaries include the helium supply system; the nitrogen buffergas supply system; the gas-sampling system; the loop-evacuation, purge, and pressure-relief system; and the electrical system.

\section{Gas Supply Systems}

Helium and nitrogen gas are supplied from cylinders located outside the secondary containment cell. Each system contains pneumatically controlled valves for maintaining the set pressures and differential pressures required for proper operation of the system. When bleeding of either the helium or nitrogen system is required to maintain the set pressure, the discharge is passed through a charcoal trap to the stack to prevent possible release of fission products from the cell.

Helium Supply System. The helium supply system is used to fill the loop with helium for operating or purging. The helium is fed from two 
standard (210-scf) helium bottles through a common manifold. A Victor Model GD-10 pressure-reducing valve is used to reduce bottle pressure to approximately loop pressure. A Research Control Company Model P-785 pneumatically controlled valve regulated from a Foxboro controller maintains the loop pressure at the desired setting.

Nitrogen Buffer Gas System. The nitrogen buffer gas system supplies nitrogen gas to the sealing ring grooves of the loop flanges and to the tubular heater terminal cavity of the main heater. Nitrogen pressure is maintained at a differential pressure of 2 psi below the loop helium pressure by means of a Foxboro pneumatic controller located in a control cabinet outside the cell.

Gas-Sampling System

In the low-temperature loop, gas samples were obtained by manifolding a 25-rn gas-sampling bottle to the loop and a vacuum pump. The gas bottle was evacuated, filled from the loop to $5 \mathrm{psig}$, sealed, removed from the manifold, and submitted for mass spectrometer analysis.

When the loop was redesigned for operation at $1500^{\circ} \mathrm{F}$, a Greentorier Instruments, Inc., chromatographic process stream analyzer was incorporated in the system for automatic impurity sampling. This chromatograph is capable* of measuring $\mathrm{H}_{2}, \mathrm{O}_{2}, \mathrm{CH}_{4}$, and $\mathrm{CO}$ in concentrations of less than 1 ppm with a cycle time of approximately $20 \mathrm{~min}$.

Loop-Evacuation, Purge, and Pressure-Relief System

At the start of each run the loop is evacuated to between 0.01 and 0.1 torr and filled to $30 \mathrm{psig}$ with helium. This mass of gas is then vented through the carbon filter, and the loop is again evacuated to between 0.01 and 0.1 torr. The loop is pressurized to 5 psig with helium to inhibit inleakage of air when the source is inserted into the injector system. Helium pressure is then adjusted so that the subsequent loop heatup will bring the loop pressure to the desired operating value for the given test. When a run is terminated the helium is discharged through char. coal traps, to remove fission products, and exhausted to the cell stack.

\footnotetext{
* See Appendix A.
} 
The 10op has two pressure-relief systems. One is a part of the loop pressure-regulating system, which vents helium through the carbon trap when the loop pressure exceeds an established set point. The other is an emergency relief valve that vents to the cell near the entrance to the cell exhaust fan.

Loop Evacuation System

Loop evacuation is accomplished in two steps. The first step consists in venting the loop helium to atmosphere, and in the second step the loop is evacuated to between 0.01 and 0.1 torr.

The venting can be accomplished in two ways. The first method is to lower the set point on the pneumatic controller, which regulates the. loop pressure. Coolant can then be released to the carbon filter and into the cell. The second method consists in manually opening the bypass valve around the loop pressure control valve to release the coolant through the carbon filter and into the cell.

The loop is evacuated with a mechanical vacuum pump. Discharge from the vacuum pump is also vented through the carbon trap before exiting into the cell. The time required for evacuating the loop to below 0.I torr varies with the past history of the loop, but in general the loop can be pumped down to less than 0.1 torr in less than $2 \mathrm{hr}$.

Electrical Supplies

Main Heater Supply. The 60 tubular heaters assembled in the main heater are grouped into three sets. Each set of 20 heaters, composed of five parallel groups of four paralleled heaters, is supplied from a phase of a l2-gang $Y$-connected variable transformer bank. All three phases of the Powerstat are actuated simultaneously by an electric motor controlled by a jogging switch on the electrical control panel.

Loop Heaters. The tubular heaters are connected to separate variable transformers in two control panels so that the temperature of each section of the loop may be adjusted individually.

Circulator Electrical Supply. Power to the circulator motor is provided by a variable-frequency generator driven through a magnetic 
hysteresis-type clutch by a 440-v induction motor. The clutch control signal can be adjusted from the electrical control panel to vary the generator frequency from 100 to $400 \mathrm{~Hz}$, corresponding to a compressor-motor speed range of 3,000 to $12,000 \mathrm{rpm}$.

Instrumentation and Controls

Approximately 52 thermocouples, 4 differential pressure-measuring instruments, 2 variable-orifice flowmeters, an orifice flowmeter, and an $\mathrm{NaI}$ ( $\mathrm{TI}$ ) gamma scintillation counter are used in the loop facility. Wherever possible, the instrumentation and controls were designed to operate the loop from outside the cell. Figure 14 shows the control panel. arrangement.

All temperature measurements are made with Chromel-Alumel thermocouples, except those in the injection system, which are made with tungsten versus tungsten-rhenium thermocouples. The thermocouples that measure outer wall temperatures were attached by flattening the thermocouple bead and spot welding the bead to the pipe wall. Where gas-stream temperatures are required, sheathed thermocouples are used. Each sheathed thermocouple was inserted through a I/16-in. tube fitting to the desired depth, and the compression-fitting nut was tightened giving a leaktight seal. All thermocouple outputs are recorded by millivolt recorders.

Pressures and differential pressure measurements are sensed and transmitted to indicators on the control panels by pneumatic transmitters. Flow measurements are made by a differential pressure transmitter coupled to the orifice section. Figure 1 indicates the location of the orifice run in the loop.

The NaI (TI) crystal detector for the pulse-height analyzer was placed in a lead shield and mounted on a dolly that runs on tracks beneath the full length of the deposition section. A collimating slot machined in the top of the lead shield was sized so that a section of the deposition section approximately $I$ in. along the axis and the total width of the tube can be seen by the crystal. In this way any incremental part of the section can be monitored by moving the crystal along its track.

The output of the scintillation detector is fed through a preamplifier to a linear amplifier. A pulse-height analyzer incorporated in the 


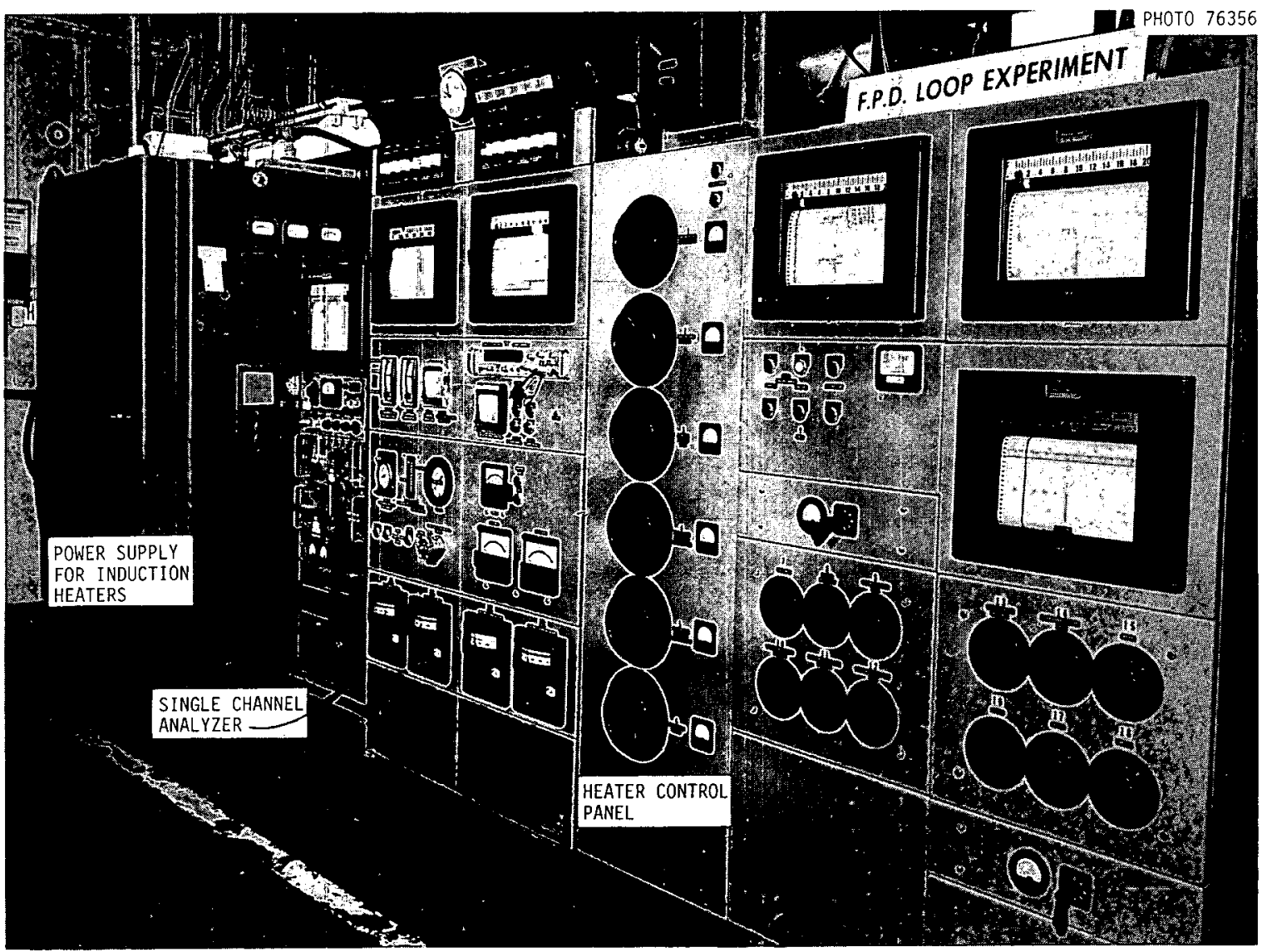

Fig. 14. FPD Loop Control Panel. 
linear amplifier is "peaked" to pass only signals equivalent to the predominant energy corresponding to the isotope being used in the loop. The output of the pulse-height analyzer is fed into a linear count-rate meter for visual display and then to a millivolt recorder for permanent recording of the count rate. Either a multichannel or single-channel analyzer will be used, depending on the requirements of the test.

Since only a portion of the gamma rays emitted by the tracer element deposited on the wall of the deposition section is detected through the collimating slot by the crystal, a calibration curve must be developed to determine the total activity on the deposition section. This is accomplished by removing typical samples from the test section that have been counted by the loop detector and calibrating them against the samples counted in a $4 \pi$ counter. Once a correlation has been established between the two counters, it can be applied to all subsequent tests in which the geometry is unchanged.

\section{Preoperation Test}

A preoperation test was made to determine the temperature profile along the loop piping and to determine correspondence between thermocouple readings located on the outer wall of the pressure pipe and corresponding locations on the deposition tubing. During normal operation it will not be possible to locate thermocouples on the wall of the deposition tube. A typical set of operating conditions during the preoperation test is listed below, and Fig. 15 shows a typical temperature profile along the loop piping during this test.

$\begin{array}{ll}\text { Maximum helium flow, acfm } & 50 \\ \text { Measured pressure drop around the } & 3.36 \\ \text { loop at a flow of } 47 \text { acfm, psi } & \\ \text { Operating pressure, psig } & 226 \\ \text { Loop volume, ft }{ }^{3} & 9.0 \\ \text { Maximum helium temperature (at } & 1200 \\ \text { main heater outlet), }{ }^{\circ} \mathrm{F} & \end{array}$

The deposition tube was instrumented with 20 thermocouples, in sets of four, spaced $90^{\circ}$ apart at each of five axial positions along the 


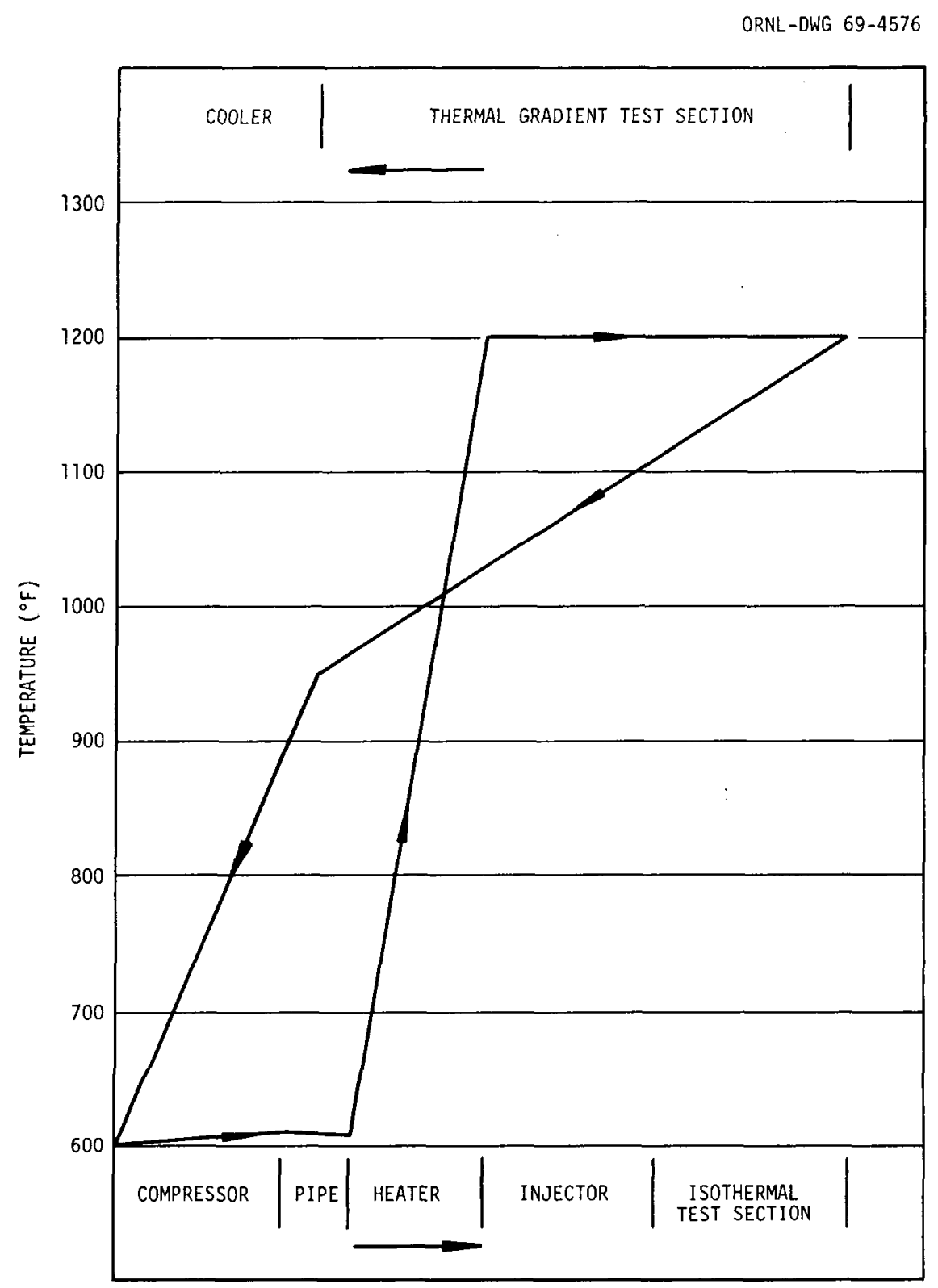

Fig. 15. Typical Temperature Profile of FPD Loop During a Preoperation Test.

* 
deposition tube. The axial positions were chosen to coincide in the transverse plane with monitoring thermocouples permanently installed on the outer surface of the test section pressure piping. Temperature readings made during the preoperation test indicate that with the loop pressurized, coolant flowing, and the heaters on the outside of the test section energized to maintain a pipe wall temperature of $1200^{\circ} \mathrm{F}$ in the deposition section, the four sets of downstream thermocouples (the four sets farthest from the injector) read within $\pm 10^{\circ} \mathrm{F}$ of the corresponding temperature readings on the outer surface of the test section piping. However, the first (upstream) set of thermocouples gave a temperature $54^{\circ} \mathrm{F}$ higher than the adjacent pipe wall temperature because of a large uninsulated pipe flange near the pipe thermocouple that provided a cold sink for the adjacent pipe.

The test indicated that during normal operation temperature readings indicated by the permanent thermocouples located on the outer wall of the pressure piping will compare closely to the actual deposition surface temperature; however, the upstream thermocouple will not reliably reflect its corresponding deposition surface temperature if the pipe flange is uninsulated. 


\section{References}

I. F. H. Neill, D. M. Eissenberg, and D. L. Gray, Iodine Transport and Deposition in a High Temperature, Helium Loop First Test Series, USAEC Report ORNL-TM-1134, Oak Ridge National Laboratory, August 1965.

2. F. H. Neill, D. L. Gray, and T. S. Kress, Iodine Transport and Deposition in a High-Temperature Helium Loop, USAEC Report ORNL-TM-1386, Oak Ridge National Laboratory, June 1966.

3. I. K. Namba, Development of Regenerative Compressor Helium Circulators, USAEC Report ORNL-TM-218, Oak Ridge National Laboratory, May 25, 1962.

4. J. Zasler et al., GCR-ORR Loop 2 Design, USAEC Report ORNL-TM-1048, Oak Ridge National Laboratory; June 1965.

5. F. A. Flint, Performance Tests for GCR-ORR Loop II Main Heat Exchangers, unpublished internal document, Oak Ridge National Laboratory, 1962.

6. Jo H. Griffin, MEC-21 A Piping Flexibility Analysis Program, USAEC Report IA-2929, Los Alamos Scientific Laboratory, July 1964.

7. ORIL Radiation Safety and Control Training Manual, June 1, 1961 (undocumented).

8. T. S. Kress, F. H. Neill, and D. L. Gray, A Fission Product Deposition Test Loop, unpublished internal document, Oak Ridge National Laboratory, 1964. 


\section{Acknowledgments}

The authors wish to express appreciation to A. S. Meyer, Jr., for his work in setting up and calibrating the gas chromatograph; to E. J. Breeding, R. D. Stulting, and R. J. Emmert of the Reactor Division Design Department for their assistance in the mechanical and electrical design; to D. L. Clark and E. M. Isees for their assistance in preoperation testing of the induction coil; to S. R. Ashton for his assistance in procurement; and to G. E. Mills for his assistance in the assembly and operation of the facility. Their help is sincerely appreciated. 
Appendix A

MODIFICATION OF A GREENBRIER GAS CHROMATOGRAPH

FOR INCREASED SENSITIVITY

C. M. Boyd* A. S. Meyer*

The fission-product deposition studies will require the analysis of helium for permanent gas contaminants at the ppm and sub-ppm levels. The process gas chromatograph available for this analysis was a Greenbrier Model 312 with a thermistor-type thermal conductivity detector. This chromatograph has given analyses with a detection limit on the order of 2 to 3 ppm.

A helium ionization detector was installed in this chromatograph to provide the needed improvement in sensitivity. In order to exploit the increased sensitivity of this new detector fully it was necessary to use high-purity helium, provided by a quartz diffusion purifier, and to make extensive changes in the circuitry of the instrument. The circuitry changes included the installation of a new attenuator timing unit and a remote-control module for the electrometer, which is positioned adjacent to the analyzer section.

With this ionization detector and a conventional column arrangement, sub-ppm detection limits were achieved for all permanent gas contaminants, except $C O$. The problem with $\mathrm{CO}$ is associated with asymmetry of the $\mathrm{CO}$ peaks when resolved on molecular-sieve columns. This asymmetry introduces negligible effects in the measurement of macro-concentrations of $\mathrm{CO}$; but when only 1 to $2 \mathrm{ppm}$ is present the co falls largely in the "tail" of the peak, where it is so diluted that it yields a broad and almost unobservable peak.

This asymmetry was removed by a novel column and oxidizer system. The sample is first passed through a silica-gel column to separate the $\mathrm{CO}_{2}$ from the other contaminants and then through a converter column of $\mathrm{I}_{2} \mathrm{O}_{5}$ at approximately $125^{\circ} \mathrm{C}$, which selectively oxidizes the $\mathrm{CO}$ to $\mathrm{CO}_{2}$. The oxidized gases are passed through a second silica-gel column to resolve the converted $\mathrm{CO}$ (as $\mathrm{CO}_{2}$ ) from the remaining contaminants, $\mathrm{H}_{2}, \mathrm{O}_{2}$,

*Analytical Chemistry Division. 
$\mathrm{N}_{2}$, and $\mathrm{CH}_{4}$, which are subsequently separated on a 13-X molecular-sieve column. With this arrangement two $\mathrm{CO}_{2}$ peaks are measured by the detector. The first contains the converted $\mathrm{CO}$ and the second the $\mathrm{CO}_{2}$ originally present in the sample. Since the co does not pass through the sieve column $\left(\mathrm{CO}_{2}\right.$ bypasses the sieve column via a dual-colum valve) the asymmetry is eliminated.

The modified chromatograph has now been installed at the FPD loop. After the addition of a system of cascaded "Sola" transformers to reduce power fluctuations, the system functioned satisfactorily. 
ORNL-TM-2532

Internal Distribution

1. S. E. Beall

2. E. J. Breeding

3. W. Bo Cottrell

4. F. L. Culler

5. R. J. Davis

6. H. J. deNordwall

7. R. J. Emmert

8. A. P. Fraas

9-12. D. I. Gray

13. P. N. Haubenreich

14. S. I. Kaplan

15. P. R. Kasten

16-17. T. S. Kress

18. E. M. Lees

19. M. I. Lundin

20. R. N. Lyon

21. R. E. MacPherson

22. H. C. McCurdy

23. A. S. Meyer
24. A. J. Miller

25-34. F. Ho Neill

35. L。 F. Parsley, Jr。

36. A. M. Perry

37. M. W. Rosenthal

38. A. W. Savolainen

39-48. Mo Do Silverman

49. M. J. Skinner

50. I. Spiewak

51. D. A. Sundberg

52-98. D. B. Trauger

99. G. M. Watson

100. G. D. Whitman

101-102. Central Research Library

103-104. Y-12 Document Reference Section

105-109. Laboratory Records Department

110. Laboratory Records Department (LRD-RC)

\section{External Distribution}

111. H. W. Brishen, GENMPO, Evendale, Ohio

112. W. E. Bull, University of Tennessee, Knoxville, Tenn.

113. A. W. Castleman, Brookhaven National Laboratory

114. J. Colby, AEC, Washington, D.C.

115. J. M. Genco, Battelle Memorial Institute, Columbus, Ohio

116-119. Gulf General Atomic Library [Attn: W. E. Bell, A. J. Goodjohn, Librarian (2 copies)]

120. R. L. Hamester, AEC, Washington, D.C.

121. D. H. Imhoff, GEAP, San Jose, Calif.

122. R. F. Kirkpatrick, AEC, Gas-Cooled Project Branch, Division of Reactor Development and Technology, Washington, D.C.

123. R. E. Pahler, AEC, Washington, D.C.

124. E. E. Purvis, AEC, Washington, D. C.

125. J. H. Russell, Los Alamos Scientific Laboratory

126. J. M. Simmons, AEC, RDT, Washington, D.C.

127. B. Singer, AEC, RDT, Washington, D.C.

128. Laboratory and University Division, AEC, ORO

129-143. Division of Technical Information Extension (DTIE) 